\title{
Law Enforcement At Sea Hinders Sea Toll Program Towards Indonesia As A Global Maritime State
}

\author{
Karolus Geleuk Sengadji*), Amin Purnawan ${ }^{* *}$ and Aryani Witasari ${ }^{* * *}$ ) \\ *) Merchant Marine Polytechnic of Semarang (PIP), E-mail:karolus.capt@gmail.com \\ $\left.{ }^{* *}\right)$ Faculty of Law Universitas Islam Sultan Agung \\ ${ }^{* * *}$ F Faculty of Law Universitas Islam Sultan Agung
}

\begin{abstract}
The purpose of this research is to identify and analyze obstacles to shipping activities and solutions for law enforcement at sea to support shipping activities/sea tolls programs. The specification of this research is descriptive analytical, and the approach to the problem is carried out in a normative juridical manner, to examine national and international laws and regulations in the shipping sector. The data used are secondary data from primary legal materials, secondary legal materials and tertiary legal materials, which are collected through literature study, and analyzed using qualitative analysis methods, and presented described descriptively. The results of the study indicate that the obstacles in shipping activities/sea tolls programs are the many law enforcement agencies at sea which have overlapping authority to stop and inspect ships at sea, so the best solution is to have an integrated security system under one civil institution to be effective and efficien to support the smooth running of the sea tolls program.
\end{abstract}

Keywords: Law; Enforcement; Sea; Tolls; Shipping.

\section{Introduction}

The Unitary State of the Republic of Indonesia is an archipelagic country consisting of 17,359 islands and 2/3 of its territory consists of oceans which have been proclaimed as a unifier of the nation with a coastline of $8.03 \mathrm{~km}$ which is the second longest coastline in the world increase economic growth in order to achieve community welfare, through the current government program, namely the sea tolls program towards Indonesia as the world's maritime axis.

Law enforcement at sea in order to support the activities of the sea tolls program, we are obliged to apply the international convention, namely UNCLOS 1982, which has been ratified by the government with Act No. 17 of 1982 concerning the Ratification of the United Nations on the Law of the Sea in 1982 called UNCLOS 1982. This convention has an important meaning for the Indonesian people because for the first time it received official international recognition as an archipelagic country after fighting for 25 years starting on December 13, 1957 through the Juanda Declaration. This convention also regulates territorial sea regimes, additional zones, exclusive economic zones, continental seas, rights and obligations of archipelagic states,

In accordance with UNCLOS 1982, each member of the United Nations is given the right to protect the coastal state (article 25), the enforcement of laws and regulations of the coastal state (article 73), the right to conduct inspections (article 110), the flag State's obligation (article 94), the obligation to avoid losses (article 
73). Article 225), the authority to enforce compliance (Article 224) and investigation of foreign vessels (Article 226). ${ }^{1}$

Since May 7, 1960, Indonesia has been a member of the world maritime organization / International Maritime Organization hereinafter referred to as IMO, with the focal point of the Directorate General of Sea Transportation / Ministry of Transportation, St. Medan Merdeka Barat no.8 Central Jakarta. In the world of shipping, Indonesia must follow the provisions / regulations issued by IMO, one of which is about the safety of life at sea (safe of life at the sea) hereinafter referred to as SOLAS 1974, Chapter XI-1 regulates Safety and Chapter XI-2 regulates security ships and ports or known as the International Ship and Port Facility Security Code, hereinafter referred to as the ISPS Code. ${ }^{2}$

Currently, the Unitary State of the Republic of Indonesia has several institutions as law enforcers at sea which have overlapping authorities that hinder the smooth running of the toll road program, including: (i) TNI-AL in accordance with Act No. 34 of 2004 concerning the TNI; (ii) Indonesian National Police / Water and Air Police in accordance with Act No. 2 of 2002 concerning the Indonesian National Police; (iii) Maritime Security Agency (BAKAMLA) according to Act No. 32 of 2014 concerning Marine Affairs; (iv) Ministry of finance / Directorate General of Customs and Excise in accordance with Act No. 17 of 2006 concerning Amendments to Act No. 10 of 1995 concerning Customs; (v) Ministry of Transportation / Directorate General of Sea Transportation according to Act No. 17 of 2008 concerning Shipping.

In carrying out law enforcement patrols at sea, each agency/institution has its own facilities/infrastructure, budget and work program so that it is less effective and inefficient. Business actors in the shipping sector, including transportation in waters and ports, really hope for legal certainty, justice and legal benefits to be effective and efficient in their efforts to participate in advancing the economy in the country, especially in the sea tolls program.

\section{Research Methods}

In this study, the author seeks to analyze the obstacles that occur in law enforcement at sea which are obstacles and how to solve them so that there is an effective and efficient law enforcement system at sea in supporting a safe, smooth and secure sea tolls program that can guarantee certainty, legal benefits and justice. The specification of this research is descriptive analytical, and the approach to the problem is carried out in a normative juridical manner, to examine national and international laws and regulations in the field of shipping/sea tolls. The data used are secondary data from primary legal materials, secondary legal materials and tertiary legal materials, which are collected through library research, and analyzed using qualitative analysis methods, and presented described descriptively.

1 United Nations Convention of Law on the Sea, (UNCLOS), 1982

${ }^{2}$ Safe of Life at Sea (SOLAS), 1974 


\section{Results and Discussion}

\subsection{Law enforcement at sea hinder the smooth running of the sea tolls program towards Indonesia as the world's maritime state}

Shipping is a unified system consisting of transportation in waters, ports, safety and security, and protection of the maritime environment ${ }^{3}$. Furthermore, Article 5 states that shipping is controlled by the state and its guidance is carried out by the government. Referring to article 5, the government is currently launching a sea tolls program which has been running for the sixth year and has proven quite effective in reducing the disparity in prices of basic necessities in the western part of Indonesia and eastern Indonesia ${ }^{4}$. Because shipping is a unified transportation system in waters and ports, in this discussion we will discuss the activities of ships when loading and unloading at ports and when ships are sailing in Indonesian seas/waters.

\subsubsection{Harbor ship activities}

Ship activities at ports for loading or unloading involve many parties, both government and business actors, where business actors in the shipping/sea toll road sector are taxpayers who comply with tax obligations as a source of state revenue, which in this pandemic period requires attention to regulatory reform taxpayers to ease the burden on business actors from corporate tax obligations as stated by Amin Purnawan in the journal Daulat Hukum. ${ }^{5}$ In addition to being obedient to paying taxes, business actors also bear very large ship operational costs in the event of an accident, because not all activities are operational. Not all ship operations including insurance can be borne by the insurer, as stated by Subekhan in the Jurnal Dulat Hukum. ${ }^{6}$

Table 1. Agencies involved in loading/unloading activities at the port

\begin{tabular}{lll}
\hline No & Agency & Task \\
\hline $\mathbf{1}$ & $\begin{array}{l}\text { Port business entities (BUMN } \\
\text { / Private) }\end{array}$ & Provide loading and unloading facilities \\
\hline $\mathbf{2}$ & $\begin{array}{l}\text { Master Harbour/ Ministry of } \\
\text { Transportation }\end{array}$ & $\begin{array}{l}\text { Checking the seaworthiness of the ship } \\
\text { Issuing a sailing approval letter }\end{array}$ \\
\hline $\mathbf{3}$ & $\begin{array}{l}\text { Customs and Excise / Ministry } \\
\text { of Finance }\end{array}$ & $\begin{array}{l}\text { Checking the load } \\
\text { Granting export/import goods permits }\end{array}$ \\
\hline $\mathbf{4}$ & $\begin{array}{l}\text { Animal and Plant Quarantine } \\
\text { / Ministry of Agriculture }\end{array}$ & $\begin{array}{l}\text { Checking cargo as carriers of viruses / } \\
\text { disease outbreaks }\end{array}$ \\
\hline
\end{tabular}

\footnotetext{
3 Act No. 17 of 2008 concerning Shipping

${ }^{4}$ Hartanto, H.; Victoria, O.A.; Chuasanga, A. Maritime Transportation in Indonesian Policy. J. Pembaharuan Huk. 2019, 6, 36-44, Jurnal Pembaharuan Hukum Unissula, Vol. 6, No. 1 (2019), http://jurnal.unissula.ac.id/index.php/PH/article/view/4657

${ }_{5}$ Amin Purnawan, 12 March 2012, Rekontruksi Sistim Pemungutan pajak penghasilan (PPh) Badan Berbasis Nilai Keadilan, Jurnal Daulat Hukum, Vol. 11, March 2012.

6 Subekhan, and Hanim,12 April 2020, Criminal Responsibility on Captain of Commercial Vessel by Act 17 of 2008 on Voyage, Jurnal Daulat Hukum, Vil.3, No.1, March 2020.
} 


\begin{tabular}{lll}
\hline $\mathbf{5}$ & $\begin{array}{l}\text { Fish Quarantine / Ministry of } \\
\text { Fisheries }\end{array}$ & Checking fish loads from disease outbreaks \\
\hline $\mathbf{6}$ & $\begin{array}{l}\text { Health Quarantine / Ministry } \\
\text { of Health }\end{array}$ & $\begin{array}{l}\text { Checking the health of the ship and the } \\
\text { health of the crew }\end{array}$ \\
\hline $\mathbf{7}$ & $\begin{array}{l}\text { Immigration / Ministry of of } \\
\text { Law and Human Rights }\end{array}$ & $\begin{array}{l}\text { Checking foreign crew members or } \\
\text { Indonesian crew members who are going to } \\
\text { or from abroad }\end{array}$ \\
\hline $\mathbf{8}$ & Shipping Company & Preparing the ship \\
\hline $\mathbf{9}$ & Owner & Providing payload \\
\hline
\end{tabular}

From the table above, it can be seen the series of activities when the ship is in a port to carry out activities, namely from the time it arrives until it departs or leaves for the destination port. Shipping companies engaged in sea transportation services provide loading space, carry out promotions and seek cargo from the owner of the goods. Furthermore, the terminal manager in this case in Indonesia at commercial ports managed by BUMN / PT. Pelindo and there are non-commercial ports that are managed by the government and there are special ports that are managed by the private sector providing space or a berth according to the length of the ship and the type of cargo to be loaded or unloaded.

The cargo to be loaded or unloaded at a port is always checked by the quarantine party, both animal and plant quarantine, fish quarantine, and health quarantine for ships and their crews, to prevent viruses or pests carrying disease from entering and leaving the territory, while the quantity of goods is checked by customs and excise officers to obtain a permit to enter/exit goods in the customs area and pay customs/excise obligations for the entry/exit of goods as state revenue.

In accordance with national and international laws and regulations, law enforcement agencies at ports or airports as entrances to a territory must exist, namely quarantine, immigration, and Customs and Excise called Quarantine, Immigration and Custom (QIC), and Harbor Master as shipping safety and security supervisor. From all the above series of activities, all institutions have carried out their duties well in law enforcement so that the ship is declared seaworthy and meets the requirements to sail to the port of destination.

\subsubsection{The ship's activities while sailing on the sea to the destination port}

When sailing to the destination port, there are obstacles because there are frequent terminations and inspections of ships by law enforcement officers at sea with their respective legal bases, thus hampering shipping activities or the smooth running of the sea toll program and causing time and material losses to business actors in the shipping sector as stated by the general chairman of the Indonesian Ships Owners Association (INSA).

Furthermore, the author analyzes the obstacles to activities when the ship sails based on international conventions and national legislation. In accordance with UNCLOS 1982 article 110, concerning the right to conduct inspections, it reads that warships may conduct inspections of a ship suspected of: (i) the ship is involved in robbery, (ii) the ship is involved in the slave trade, (iii) the ship is involved in illicit broadcasting, (iv) the vessel is without nationality. Furthermore, Article 224 concerning the exercise of the authority to enforce compliance, states that the 
authority to force the registration of foreign vessels according to this chapter can only be exercised by officials or by warships, military aircraft, or other marine vessels. ${ }^{7}$ To know aircraft that have clear and recognizable markings and are in government service and authorized to carry out these actions. Based on UNCLOS 1982, articles 110 and 224, are linked to Act No. 34 of 2004 concerning the Indonesian National Armed Forces (TNI). Article 5 and 6 concerning the role of the TNI are as a state instrument in the security sector to ward off every form of military threat and armed threat both from outside and within the country in order to defend the sovereignty, integrity, territory and safety of the nation. Referring to articles 110 and 224 of UNCLOS 82, law enforcers or the crew of the Republic of Indonesia Warship (KRI), should not stop and inspect commercial ships at sea because commercial ships only load goods or cargo from island to island, not armed and does not commit piracy, or conduct illicit broadcasting and has a nationality as evidenced by flying the red and white flag on the back mast of the ship.

In addition, in law enforcement at sea there are also state (civilian) vessels that have a recognizable identity, namely state vessels belonging to the Indonesian National Police, Customs and Excise and KPLP, which carry out safety and security patrols at sea, so it is necessary ${ }^{8}$ there is a clear separation of authority between the TNI and civilians. The overlapping authority of law enforcement at sea was also conveyed maritime expert from the Surabaya Institute of Technology (ITS) Raja Oloan Saut Gurning totempleut berita Bisnis.com, Rinaldi Muhammad Azka that there are 18 law enforcement agencies at sea, which have overlapping authorities, making the role of authority at sea unclear. Extortion (illegal levies) may be just an impact, but this overlap is in real terms burdening and disrupting other transport processes and our maritime business.

Referring to there is a law enforcement theory, according to Soerjono Soekanto, quoted by HS Salim and Erlies, ${ }^{9}$ there are five factors that must be considered in law enforcement, namely (1) legal factors or laws; (2) law enforcement factors; (3) Suggestions and facilities factors; (4) Community factors and (5) Cultural factors.

Based on law enforcement theory, the author analyzes several national laws and regulations that describe the overlapping authority of law enforcers at sea which is said to be an obstacle to the smooth running of the sea tolls program, including:

(1) Act No. 34 of 20049 concerning the Indonesian National Army (TNI). Article 5 and 6 concerning the role of the TNI are as a state instrument in the security sector to ward off every form of military threat and armed threat both from outside and within the country in order to defend the sovereignty, integrity, territory and safety of the nation.

\footnotetext{
${ }^{7}$ Act No. 34 of 2004 concerning the TNI.

8 Rinaldi Muhamad Akza, date 20 August 2019, Ada 18 Instansi Penegak Hukum Di Laut, Jaditumpangtindih, Saut Gurning, https://ekonomi.bisnis.com.ada Accessed June 20, 2021.

9 Salim HS dan Erlis, 2017,Penerapan Teori Hukum Pada Penelitian Tesis Dan Disertasi, Pt. Raja Grafindo,Depok, p. 303
} 
(2) State Act No. 2 of $2002^{10}$. In the Act it is stated that the main tasks of the Police are (i) maintaining security and public order, (ii) enforcing the law, (iii) providing protection, protection and services to the community.

(3) State Act No. 17 of 200611 concerning amendments to Act No. 10 of 1995 concerning Customs. In this Law, the main task of Customs and Excise is to supervise the traffic of goods entering or leaving the customs area and to collect import and export duties.

(4) Act No. 17 of $2008^{11}$ concerning Shipping. In article 276 paragraphs (1) and (2) the Marine and Coastal Guard Unit has the function of guarding the sea and coast to ensure the implementation of safety and security at sea and the enforcement of laws and regulations at sea and coast.

(5) ${ }^{12}$ Act No. 32 of 2014 concerning the Marines, according to article 61, has the task of carrying out security and safety patrols in Indonesian waters and Indonesian jurisdictions.

The five laws are the basis for law enforcement at sea which is an obstacle to the smooth running of the sea tolls program, because ships carrying goods or cargo from island to island are stopped and inspected in the middle of the sea, even though before leaving the ship has been checked by officers from the same institution, declared eligible to sail.

Further analysis in article 225 of UNCLOS 1982 concerning the obligation to avoid adverse consequences in the exercise of the power to enforce compliance reads. In exercising the authority to enforce compliance in accordance with this convention on foreign vessels, states must not be allowed to endanger the safety of shipping or in any other way that creates a hazard to the vessel or carries her to an unsafe port or berth or marine environment from an unreasonable risk. And article 110 paragraph (3) which states: If the suspicion is unfounded and if the ship being inspected does not perform an act that justifies the inspection, the ship will receive compensation for any loss or damage that it may suffer. However, the reality is that business actors in the shipping sector have never received compensation. This requires justice in the application of law in accordance with the perspective of Islamic law, because the settlement of cases is currently still based on the Criminal Code so that there is a need for legal reform as stated by Sri Endah in the Jurnal Daulat Hukum. ${ }^{13}$

In addition to the absence of legal certainty and a sense of justice for business actors, there are losses arising from accidents during termination and inspection, as well as compensation on the highway as stated by Hesti in the legal sovereign journal in the event of a transportation accident on the highway, because of accident insurance at sea, only intended for hull insurance, ship machinery and marine pollution. ${ }^{14}$

\footnotetext{
${ }^{10}$ Act. 17 of 2008 concerning Shipping

11 Ibid

${ }^{12}$ Act. No. 32 of 2014 concerning Marine Affairs

13 Sri Endah Wahyuningsih, 2018, Model Pengebangan Asas Hukum Pidana dala KUHP Berbasis NilaiNilai KeTuhanan Yang Maha Esa, https://scholar.go.id. Accessed on 4 August 2021.

14 Hesti, and Sri Kusriyah, 1 March 2012, Owners Responsibilities of Vehicles use asa Illegal publicTransport When Traffic Accidents Happened, Jurnal Daulat Hukum, vol. 4, March 2021
} 
The five national laws and the three articles of UNCLOS 1982 which must be obeyed by business actors in the shipping sector but on the contrary it becomes an obstacle in doing business, including running the sea tolls program that has been launched by the government so that there needs to be a solution in the future.

\subsection{Law enforcement solutions in the shipping sector}

In accordance with the theory of legal effectiveness that examines and analyzes the success, failure and influencing factors in the implementation and application of the law.16. There are three focuses of study in the theory of legal effectiveness, namely:

- Success in law enforcement

- Failure in law enforcement

- Factors that influence it

From the activity of stopping and inspecting ships in the middle of the sea, by several law enforcement agencies creates unrest for business actors in the shipping sector, because it greatly disrupts the ship's operating schedule and can cause losses due to owner claims for delays in receiving goods, and can be said to interfere with national economic activities and no ${ }^{15}$ Supporting the sea tolls program towards Indonesia as the world's maritime axis is a failure in the application of law enforcement laws in the shipping sector, but the absence of piracy and robbery shows the success of the Navy, has maintained the sovereignty of the Unitary Republic of Indonesia and prevented the disturbance of armed groups both from outside and from within the country.

When viewed from the factors that influence the authors analyzed in this study to be able to find the best solution in the future, among others:

- In terms of institutional and legal substance. Currently, there are five law enforcement agencies at sea with overlapping legal substances, starting with the process of forming laws by the legislature, namely (i). Act No. 34 of 2004 concerning the TNI, the drafter of which is the TNI Headquarters (MABES), and discussions in the DPR RI, together with members of the Council from Commission I, (ii). Act No. 32 of 2014, the drafter is the Ministry of Maritime Affairs and Fisheries, and the discussion in the DPR RI, together with Commission IV, (iii). Act No. 2 of 2002, concerning the Indonesian National Police, the drafter is the POLRI Headquarters, the discussion in the House of Representatives with Commission I, (iv). Act No. 17 of 2006 concerning Customs, the drafter is the Ministry of Finance and discussion in the DPR RI with Commission VII, and (v).

- In terms of cost / budget. The five law enforcement agencies at sea are government agencies so that all operational costs consist of, office buildings, patrol boats, airplanes, logistics consisting of (food for crew members, fuel and lubricating oil for ships, ship maintenance / repairs), all of which are sourced from the very large state Revenue and Expenditure Budget, resulting in wastage or inefficient in terms of cost.

15 Salim HS Op.cit 
- From an operational point of view. From an operational point of view, each institution based on their respective budget support makes a work program or patrol plan at sea, each of which is not coordinated because each is under the command or supervisory agency itself so that the placement of patrol boats is not evenly distributed throughout the territory of the Republic of Indonesia. This has been proven when Indonesia has the BAKORKAMLA (Marine Security Coordination Agency) which has now been merged into BAKAMLA, only has coordinating authority and has no commanding authority so that it is less effective from an operational perspective.

From the advantages and disadvantages of the three factors mentioned above, it is hoped that a solution for enforcement agencies at sea which is handled by one agency or institution will be more effective in the operational system and more efficient in terms of costs. This is in line with the expectations of business actors in the shipping sector, especially the transportation business in waters, as conveyed by the deputy general chairman of field III, the INSA Central Executive Board, telling Sri Mas Sari from media Bisnis.com that there are 18 law enforcement agencies at sea. , INSA needs a single agency, because many law enforcement agencies at sea often stop and inspect ships at sea, causing loss of arrival time and declining quality of goods which results in a decreased selling value. ${ }^{16}$

\section{Closing}

The results of the research and discussion above can be concluded that the obstacles to the smooth running of the sea tolls program are caused by the many law enforcement agencies that have overlapping authorities, stopping and inspecting ships at sea so that they disrupt the ship's operating schedule and cause losses for business actors in the shipping sector. The best solution to ensure the smooth running of the sea tolls program towards Indonesia as the world's maritime axis, is the need for a civil institution authorized to implement law enforcement at sea to be more effective in the operational system and more efficient in terms of state costs/budgets.

\section{References}

\section{Journal}

[1] Hartanto, H.; Victoria, O.A.; Chuasanga, A. Maritime Transportation in Indonesian Policy. J. Pembaharuan Huk. 2019, 6, 36-44, Jurnal Pembaharuan Hukum Unissula, Vol. 6, No. 1 (2019), http://jurnal.unissula.ac.id/index.php/PH/article/view/4657

[2] Sri Mas Sari, on 20 August 2019,Ternyata ada 18 Instansi penegak hukum di laut, INSA perlu badan tunggal, https://ekonomi.bisnis.com, accessed on 29 June 2021. 
[3] Rinaldi Muhammad Azka, on 20 August 2019, Ada 18 Instansi Penegak Hukum Di Laut, Jadi Tumpang Tindih, Saut Gurning, https://ekonomi.bisnis.com, accessed on 29 June 2021.

[4] Theresa Sandra Desfika, on 12 May 2020, INSA keluhkan maraknya penangkapan kapal indonesia di laut sendiri, https://www.beritasatu.com, accessed on 29 June 2021.

[5] Sri Endah Wahyuningsih, 2018, Model Pengebangan Asas Hukum Pidana dala KUHP Berbasis Nilai-Nilai KeTuhanan Yang Maha Esa, https://scholar.go.id. Accessed on 4 August 2021.

[6] Hesti, and Sri Kusriyah, 1 March 2012, Owners Responsibilities of Vehicles use asa Illegal publicTransport When Traffic Accidents Happened, Jurnal Daulat Hukum, vol. \$, March 2021.

[7] Amin Purnawan, 12 March 2012, Rekontruksi Sistim Pemungutan pajak penghasilan (PPh) Badan Berbasis Nilai Keadilan, Jurnal Daulat Hukum, Vol. 11, March 2012.

[8] Subekhan, and Hanim,12 April 2020, Criminal Responsibility on Captain of Commercial Vessel by Act 17 of 2008 on Voyage, Jurnal Daulat Hukum, Vol.3, No.1, March 2020.

\section{Books}

[1] H. Salim dan Ernis Septiana, 2017, Penerapan teori hukum pada penelitian disertasi dan tesis, Rajawali Pers, Depok.

[2] Lexy J. Moleong, 2002, Metode Penelitian Kualitatif, Remaja Rosdakarya, Bandung.

[3] Morojohan JS Panjaitan, 2017,Perubahan Undang-Undang berdasarkan UUDN45, Bandung, Pustaka Reka Cipta, 2017

[4] Munir Fuady, 2018, Metode Riset Hukum, pendekatan teori dan konsep, Depok, Rajawali pers, Depok .

[5] Putera Astomo, 2018, Ilmu Perundang-undangan, Teori dan praktek di Indonesia, Raja Grafindo Persada, Depok.

[6] Sugiyono, 2012, Metode penelitian Kualitatif R\&D, Alfabeta, Bandung.

[7] Wisnu dkk, 2020, Tol Laut,Konektivitas Poros Maritim Dunia, Jakarta, Kompas Penerbit Buku.

\section{Regulation}

[1] Constitution of the Republic of Indonesia 1945

[2] Act No. 34 of 2004 concerning the Indonesian National Army.

[3] Act No. 2 of 2002 concerning the State Police of the Republic of Indonesia.

[4] Act No. 17 of 2006 concerning Customs

[5] Act No. 17 of 2008 concerning Shipping

[6] Act No. 32 of 2014 concerning Marine Affairs

[7] Government Regulation (PP) number 21 of 2010 concerning transportation in waters. 